\title{
Health accounts from past to present for a political arithmetic
}

\author{
Magdalena Rathe, ${ }^{1}$ Patricia Hernández, ${ }^{2}$ Cornelis Van Mosseveld, ${ }^{3}$ Claudia \\ Pescetto, ${ }^{4}$ and Nathalie Van de Maele ${ }^{5}$
}

Suggested citation Rathe M, Hernández P, Van Mosseveld C, Pescetto C, Van de Maele N. Health accounts from past to present for a political arithmetic. Rev Panam Salud Publica. 2018;42:e89. doi: https:/ /doi.org/10.26633/ RPSP.2018.89

ABSTRACT This report traces the progressive expansion of health accounts (HA) to measure national health expenditures, from the first attempts in 1926 by the American Medical Association to the present day. Milestones in the development of A System of Health Accounts (SHA) are covered, from the economic background to initial efforts by a few countries and organizations, to the need for a set of accounting standards for health care systems, and finally, to consolidation with SHA 2011. International organizations, such as the World Health Organization, Organization for Economic Cooperation and Development, Eurostat, the World Bank, and the United States Agency for International Development have been critical to expanding national HA exercises and ensuring that these are standardized, comparable, and become institutionalized.

National efforts to track health expenditures have not only enriched collective results, but have become an important component of global leadership, informing policy the world over. More than 100 countries have created HA under the global standard and have gained a better understanding of health spending and financial flows. These results are key for monitoring progress toward national and global initiatives, such as the Sustainable Development Goals and Universal Health Coverage. Challenges remain to be tackled, among them institutionalization and quality of results. Social responsibility for improving data sources and expanding the generation and usability of health accounts are also needed.

Keywords Health expenditures, standards; health economics, history; health planning, economics; world strategies.

There is a strong link between health and economic development. Investment in health accelerates economic growth

\footnotetext{
Plenitud Foundation, Santo Domingo, Dominican Republic.

2 Nederlands Interdisciplinair Demografisch Instituut, Den Haag, Zuid-Holland, the Netherlands.

3 Consultant, Den Haag, Zuid-Holland, the Netherlands. Send correspondence to Cornelis Van Mosseveld, vanmosseveldc@gmail.com

4 Pan American Health Organization, Washington, DC, United States of America.

5 World Health Organization, Geneva, Switzerland.
}

and contributes to poverty reduction (1). Health spending can support Universal Health Coverage, and financial monitoring can contribute to effectiveness, efficiency, equity, and empowerment of all stakeholders (2). The aim of monitoring health finances is to improve strategies to capture and allocate resources, reduce waste, and ensure financial protection. Health Accounts (HA) are a strategic tool for monitoring and evaluating reforms to health systems and for supporting the day-to-day management of resources. The World Health Organization (WHO) declared that HA are "essential information" for the analysis of health system performance, just as mortality data are essential for analyzing the health situation of a country. In 2011, the World Health Assembly approved the recommendation of reporting health expenditures using standardized rules (3).

Recently, the Pan American Health Organization's Strategy for Universal

This is an open access article distributed under the terms of the Creative Commons Attribution-NonCommercial-NoDerivs 3.0 IGO License, which permits use, distribution, and reproduction in any medium provided the origin work is properly cited. No modifications or commercial use of this article are permitted. In any reproduction of this article there should not be any suggestion that PAHO or this article endorse any specific organization or products. The use of the PAHO logo is not permitted. This notice should be preserved along with the article's original URL. 
Access to Health and Universal Health Coverage referred concretely to the need to "increase and optimize public financing for health" (4) or investment in health, specifically from public sources. This statement boosted an interest in measuring health expenditure. Health accounting needs political and institutionalized support to be sustainable, continuous, and technically solid. But which factors determine whether health accounting is considered essential for health systems? After recognizing the importance of health accounts, did any-thing change in their production or use? What has been the evolution of health accounts in the world?

The objective of this paper is to present the milestones reached during the course of developing A System of Health Accounts (SHA), from its inception to the present day. The development periods are delineated as (a) the foundation, i.e., the economical background common to national accounts; (b) the initial efforts made by a few countries and organizations; (c) the proposal for the first SHA as a standard for health system accounting; and (d) consolidation with SHA 2011.

\section{FOUNDATION}

There are accounting records in all major cultures of civilization. The origin of macroeconomic and social accounts can be linked to Aristotelian philosophy, which identified value as the basic unit for exchange and the relationship between price and quantity to measure it. About 20 centuries later, in 1664, William Petty rediscovered the idea and began the story of macroeconomic accounting (Box 1).

The work of authors such as Quesnay, Marx, Popov, Kuznets, Keynes, Clark, and Stone (5) contributed to what is now known as a "System of National Accounts" (SNA). Institutionally, the effort was linked to the League of Nations, which later became the United Nations, and to the Organization for European Economic Cooperation (OEEC), which later became the Organization for Economic Cooperation and Development

\section{BOX 1. Political Arithmetic: the study of the economic and demographic} statistics of a state.

Petty declared that his form of science would only use measurable phenomena and would seek quantitative precision, rather than relying on comparatives or superlatives. As a modern economist, he proved his claims through data and statistics, not anecdotal evidence (5).
(OECD). As shown in Figure 1, the conceptual structure of the SNA was revised in 1960, 1964, 1968, 1993, and 2008 (6). The European Union's (EU) equivalent, the European System of Accounts (ESA), was revised in 1970, 1995, and 2010, and is mandatory for EU Member States (7). The SNA 1993 included a chapter on satellite accounts, replicating or adjusting the central system to answer specific branch policy questions; later, SNA 2008 (8) referred to SHA as the satellite account for health.

\section{INITIAL EFFORTS}

\section{Pioneers}

The United States and several countries of the European Union have been pioneers in developing and using health accounting for policy decision-making.

In 1932, a working group of the American Medical Association published a health spending report for the year 1926 (9). The United States federal health programs and its Social Security Administraaround 1960s. Since then, the Health Care Financing Administration (now the Center for Medicare and Medicaid) has published estimates of public and private health financing flows annually in the world's largest health spending country. The estimates include how much money is allocated to health, who pays, and for which services. The estimates to date also cover direct household expenditure, hospital revenue, and beneficiary groups. The reports contribute to analyzing key problems, such as health spending growth, imports and exports of services and medicines, expenditure on human resources, and analysis of financial crises (10).

In France, health care consumption has been measured since 1950 (11). The National Institute of Statistics and the Ministry of Health have published data from 1979 onwards. The accounts have been used in public policy debate to discuss aspects, such as the consumption of medicines and the cost of illness, in greater depth. tion applied accounting to health finance
Statistics Netherlands published the country's first report of health costs and financing in 1957 (with data on 1953), estimating providers and financing. Since 1972, health spending has been published annually; up until the year 2000, these reports included the cost structure of the providers and investments. Since 2000 , the reports comprise health and social spending data that address Ministry of Health policy needs and support efforts to get closer to National Accounts (NA). The Ministry deals with health and social care, and has prepared a political analysis of the accounts since the early 1980s (12).

The German Statistical Office published health expenditure in the 1980s with a 5-year time-lag. By the 1990s, data were made accessible to decision-makers, 5 months after the close of each year. These reports initially included health financing data, information on who provides services and with which inputs, and later, human resources and disease analysis (13).

\section{International organizations}

In the 1960s, WHO sponsored a study group for six countries (14) to evaluate their financial means and their health service providers (who provides which services and with what inputs). Another study of 14 countries followed in 1967 (15), with a systems perspective. Over the next decades, measurements focused on national efforts to finance public and private health entities. However, the lack of a general homogeneous framework and the need for greater comparability were evident.

In 1977, the OECD published Poullier's first international comparison based on national accounting concepts (16), showing a decade of health spending data and prospective scenarios. His second compendium (17) included expenditure, price, and volume data, and promoted the idea of annual monitoring of historical series of financing, production, and outcome indicators to support health policies. Since 1991, this effort has been consolidated with the annual health data report available online from www.OECD.Stat (for Member States and associated countries).

Since the 1980s, the OECD has organized annual meetings on data and methodological analysis, including health accounts. Countries have progressively 
FIGURE 1. Foundation of the System of Health Accounts

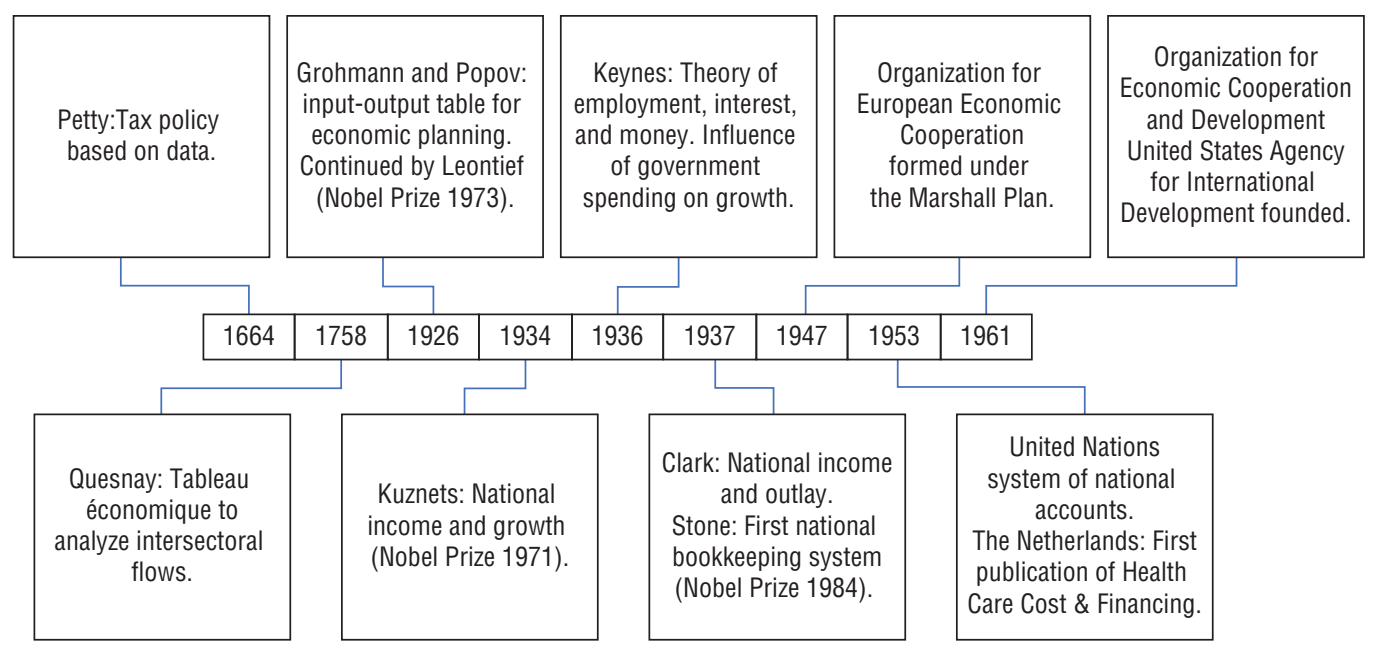

Source: Prepared by the authors from study data.

taken over this effort to collect data on health care spending.

In 1993, the World Bank published a report discussing the importance of health expenditure (18). It fueled support for health accounts and encouraged some countries to follow suit.

\section{Advances in the rest of the world}

Two elements promoted the development of health accounts in the world: the need for financial health analysis linked to health care reforms and the support of donors willing to facilitate the process. In Latin America, the first country to develop health accounts was Mexico in 1994. Health accounts were part of an analysis to sustain the health care reform with evidence (19). This exercise measured who pays for health care, where the funds originate, and who provides which services with what inputs. In Peru, the first health accounts started in 1996 and were fundamental to sustaining the country's health care reforms (20).

In 1996, the Pan American Health Organization (PAHO) and the Partners for Health Reform, funded by the United States Agency for International Development (USAID), supported the following eight Latin American countries (LAC) by jointly producing health accounts: Bolivia, the Dominican Republic, Ecuador, El Salvador, Guatemala, Honduras, Mexico, and Nicaragua. The idea was to have Latin America build on the experience of the United States, where health systems are more fragmented and a larger share of spending is private (21). In shared partnership, PAHO, the World Bank, Inter-American Development Bank (IDB), and USAID proposed to cover Latin America with health accounts within 5 years. Within 2 years, the LAC experience was showing a need for increased comparability of results from differing countries.

In the rest of the world, the impetus of USAID and WHO to steer the production of health accounts helped create regional networks in Africa, Asia, and the Middle East. Some of these networks are institutionalized today (Figure 2).

\section{FIRST STANDARD}

Comparability concerns among OECD Member States led to the "common comparable packages" project, which tested clusters of activities that could be used as common building blocks. This project was part of the preliminary work for SHA (22). Responding to the need for greater methodological consistency, OECD published SHA 1.0 (23) in 2000. The triaxial framework focused on final consumption and sought to contribute to health system decisions by analyzing expenditures according to services (functions), their financing, and their providers. These classifications were derived from NA (classifications by industry and purpose), including an aggregate of capital expenditure. Additional information on trade and the distribution of expenditure by age, sex, and disease were proposed in the manual, but not added to the classification structure. SHA facilitated the international comparability.

In most OECD countries, the work on HA was linked to statistical offices. In low- and middle-income countries, the efforts were promoted by the Ministries of Health. In 2003, WHO, the World Bank, and USAID published the "Producer's Guide" to explain SHA implementation (24). The guide also included resource costs (inputs), sources of financing, and emphasized the distributions by beneficiary group: socioeconomic status, location, disease, age, and sex.

The World Bank and other regional development banks have supported HA, even including them as a requirement for some loans. This practice continues today at institutions such as the Global Fund. The WHO Regional Offices, USAID, and the countries themselves made efforts to initiate the estimates in a standard and comparative effort.

The 2000 World Health Report (25) issued by WHO launched the annual publication of health expenditure indicators for all Member States (26). Currently, data are published on the Global Health Expenditure database, the first global, public, effort of its kind. Its data are reproduced in allied publications by the World Bank and others.

\section{Country work by region}

Countries have advanced the SHA process collectively in different ways. The Asia Pacific Health Accounts Network (27) started early in the 2000s and promoted 
FIGURE 2. Initial efforts by countries and organizations using health accounts (HA) to measure health spending, $1963-2001$

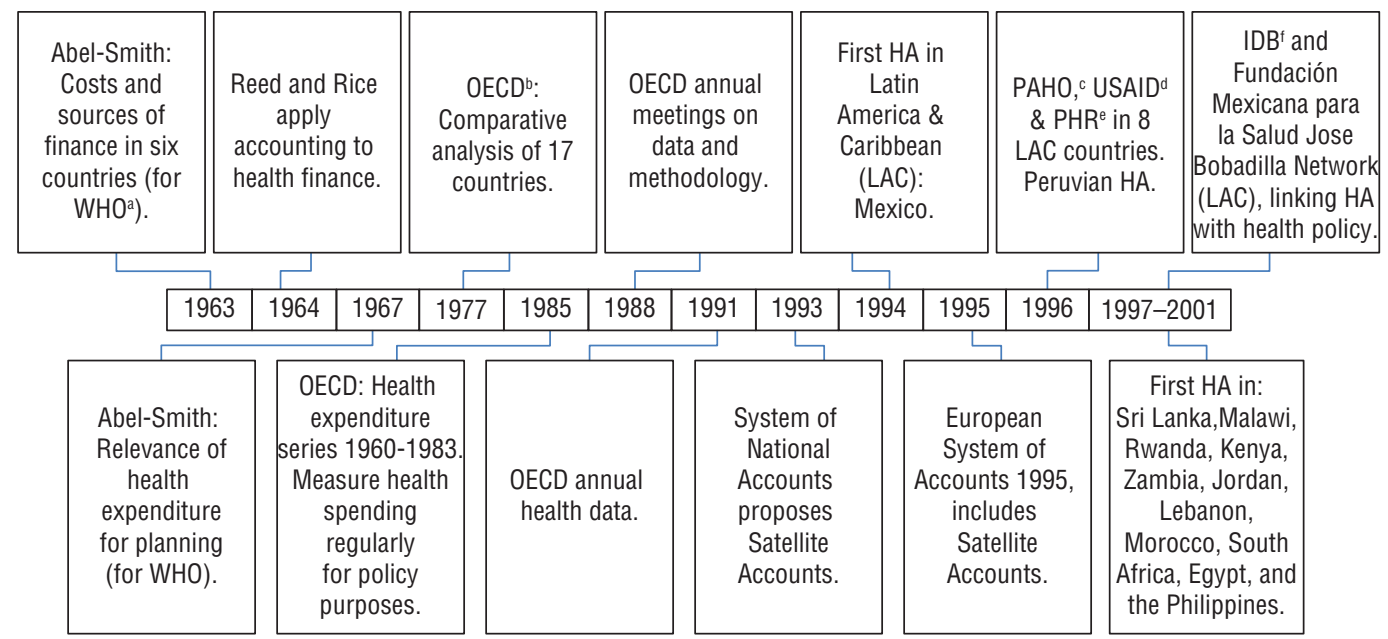

a World Health Organization.

${ }^{b}$ Organization for Economic Cooperation and Development.

c Pan American Health Organization.

d United States Agency for International Development

e Partners for Health Reform.

f Inter-American Development Bank.

Source: Prepared by the authors from study data.

quality HA through methodological, collaborative, and dissemination efforts, assisting decision-making and country ownership. This network now collaborates with the OECD Korean Policy Center and the WHO Southeast Asia and the Western Pacific Regional Offices. OECD, WHO, and the EU Member States have used a SHA Joint Health Accounts Questionnaire since 2005 for standard, efficient, and collabor-ative reporting.

In 2008, the Network of Health Accountants in the Americas (REDACS) was created (28). It is supported by WHO, Instituto Tecnológico de la Universidad de Santo Domingo (Santo Domingo, the Dominican Republic), the Ministry of Health of the Dominican Republic, Fundación Mexicana para la Salud (the Mexican Health Foundation, Mexico City, Mexico), the IDB, and USAID. REDACS is coordinated by Fundación Plenitud, within the framework of the LAC Health Observatory (Mexico City, Mexico). The network aims for high quality HA for decision-making using SHA.

PAHO published and promoted the satellite accounts manual in 2005 (29) with the purpose of extending the central framework applied to health systems. The focus is on production, consumption, and income-generation. Countries such as Brazil, Ecuador, and Portugal have developed complete data series using this model. Chile and Paraguay developed public sector series. Other countries, such as Norway, made a shortcut to the central framework linked to SHA. The satellite accounts proved to be complementary to SHA offering policy makers different, but important views of the health system (30). Satellite accounts have supported the discussion with Ministries of Finance to defend the allocation of public resources.

Since 2000, the African Region has been fully immersed in the preparation of SHA, with WHO support. Currently, Western Africa is a sub-region where HA has reached the largest participation in the field, with relevant linkages to national and regional policies, such as the Abuja Declaration (31). This agreement includes a goal of devoting $15 \%$ of government spending to health care annually.

Extensive work has been accomplished by tracking the use of resources directed to specific programs such as reproductive health $(32,33)$, HIV/AIDs (34), and tuberculosis and malaria (35). These are referred to as subaccounts, as they aim to track resources related to a specific disease. All too often, the initial support offered by financial donors to fight specific diseases is phased out. This has drawn the attention of policymakers to the need for government-supported, sustainable financing (Figure 3).

\section{CONSOLIDATION WITH SHA 2011}

Discussions at the international working group annual meetings among Eurostat (Working Group on Public Health, European Commission, Luxembourg), OECD (Health Accountants Expert Meeting), and WHO made evident the various and differing interpretations of the SHA 1.0 framework. The experience gained working with SHA 1.0 allowed the groups to identify the need for a revision. Eurostat, OECD, and WHO coordinated the revision process as the International Health Accounts Team and designated OECD as the secretariat. Consultations included regional and global meetings with 130 participating countries and international agencies, including the World Bank and IDB. The experts' vision was complemented by pilot experiences (36) to test the feasibility and ensure the migration of the existing expenditure series to the new proposal. The revision process began in 2006 and ran for 5 years, producing SHA 2011 as the new global standard endorsed by the United Nations Statistical Office. Complementary and simultaneously, the World Bank launched its "Guide for Institutionalization of Health Accounts" (37).

The aim of SHA 2011 is to achieve greater comparability and evaluate performance, regardless of the diversity of existing health systems in the world. 
FIGURE 3. Standardization leading to A System of Health Accounts (SHA), $1994-2010$

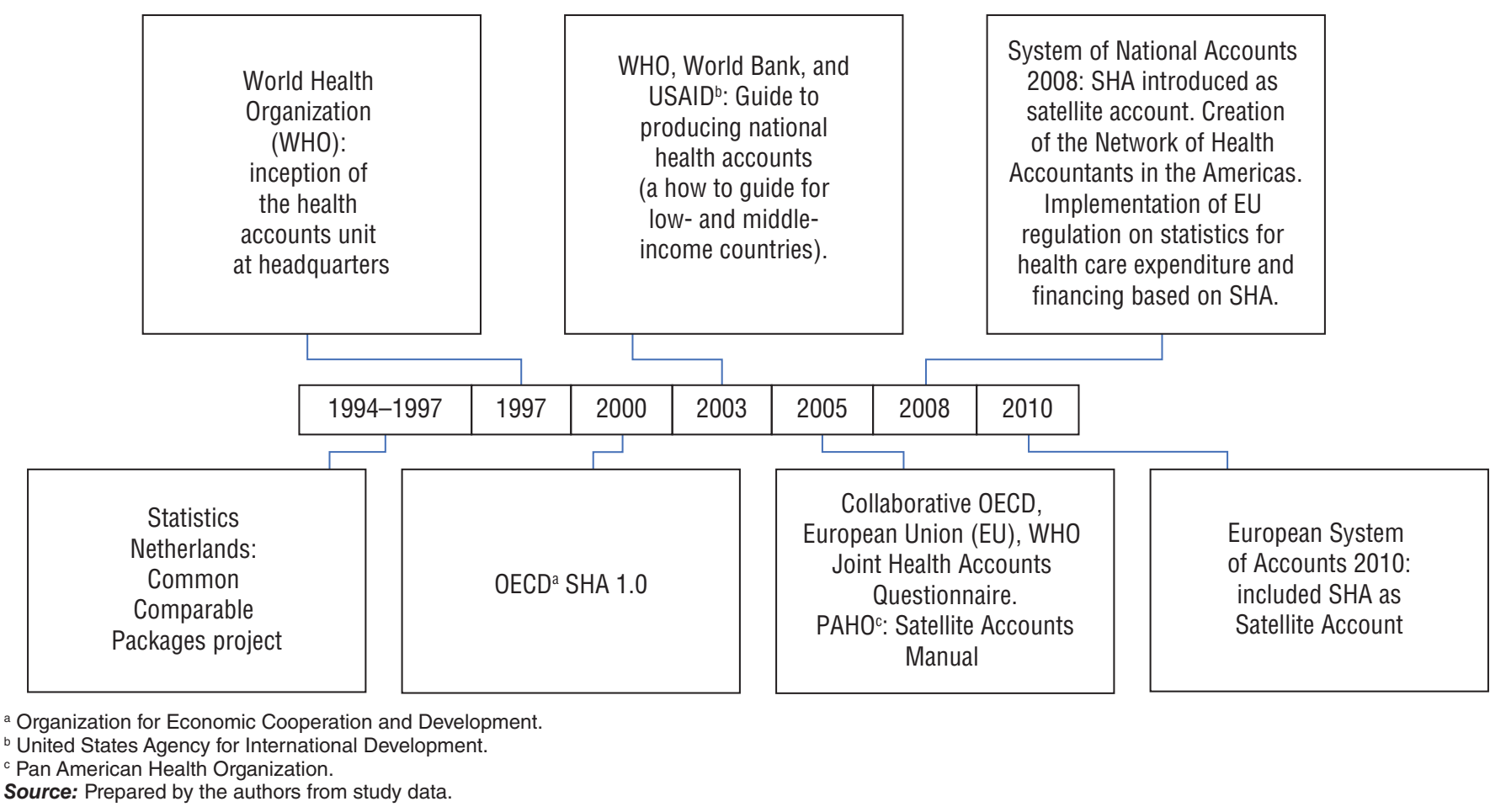

It seeks to increase standardization, consistency, and policy relevance, and to facilitate the continuous generation of health accounts and their use in decision-making. The most important changes from SHA 1.0 to SHA 2011 are a stronger link of financing functions (revenue collection, pooling and allocation/ purchase of services) with accounting classifications for a more sound representation of the health financing system, a classification of fixed capital formation to better analyze current and capital spending, and minor refinements related to prevention, non-profit institutions, and external resources. For consistency purposes, SHA 2011 proposes a complete distribution of expenditure by major disease groups (per the International Classifications of Diseases-10 or global burden of diseases) rather than by sub-accounts.

The European Union indicated in its 2015 regulation on health care expenditures (38), that beginning in 2016, SHA 2011 should be used to classify functions/services, health providers, and health care financing. OECD, Eurostat, and WHO have developed complementary guides and tools on relevant topics, such as financing, prevention, administration, medicines, capital, and disease. WHO developed two software tools to facilitate the generation of accounts: "The Health Accounts Production Tool" and "the Health Accounts Analysis Tool" to support institutionalization, the production and analysis of data, and to streamline the use of results. A revised version of SHA 2011 was released in 2017 (39) preserving the content, but improving clarity (Figure 4).

\section{Institutionalization challenges}

HA teams focus to institutionalize SHA 2011, its method, principles, data, and records. Existing series have been made compatible with SHA 2011, while incorporating the changes proposed by the new standard. All this has led to an increase in the quality of estimates. $\mathrm{WHO}$, the EU, and OECD started data collection according to SHA 2011 in 2016, and reporting in 2017. Participation is mandatory for EU Member States.

To date, many countries have generated accounts, but have failed to institutionalize them. Institutionalization is not only about data collection and regular production, but also about the use of results in policy decisions. In 1980, about 15 countries, mainly of the OECD, had produced health accounts; by 2000, the number had increased to 87; in 2010, to 130 countries; and by 2017, to about 160 countries (40). In 2017, a total of 72 non-OECD countries produced at least one SHA 2011 exercise, and of these, $30-40$ countries produce health accounts in a routine and institutionalized manner. However, there are still some countries that have done so only once, do not generate accounts on a continuous basis, or do not use HA for policymaking. This implies that institutionalization is still required.

\section{DISCUSSION AND CONCLUSIONS}

The current global standard, SHA 2011, is the result of a lengthy development process, beginning with the first attempts to account for health expenditure in the mid-20th century, without any specific taxonomy, to the manual published in Paris in 2011. SHA 2011 is compatible with national accounts and was drawn-up by experts in health financing, health systems, and health accounting who collaborated to reach consensus on classifications and definitions.

With SHA 2011, generating indicators that link resources to health outcomes or to other variables of interest for policy purposes is feasible. Key issues such as 
FIGURE 4. Consolidation of the System of Health Accounts 2011 (SHA 2011), 2006 - 2018

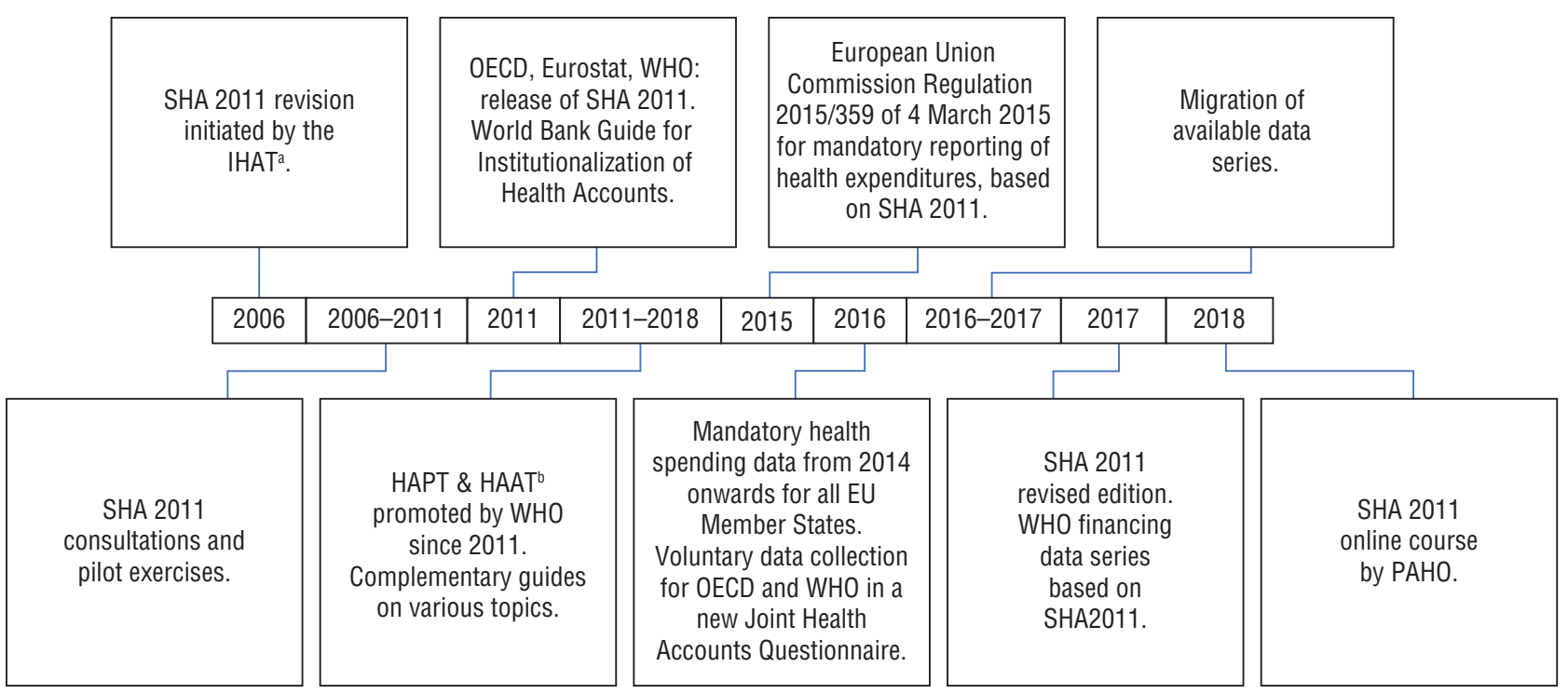

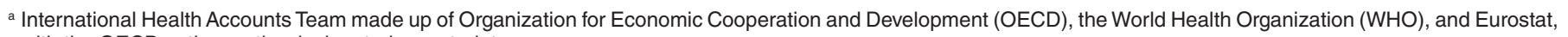
with the OECD acting as the designated secretariat.

The Health Accounts Production Tool and the Health Accounts Analysis Tool.

Source: Prepared by the authors from study data.

equity, efficiency, and quality can be routine addressed and institutionalized to increase transparency and accountability and strengthen health system governance. SHA 2011 is a bridge to financial health policy and its analysis.

The Commission on Information and Accountability for Women's and Children's Health (41) has proposed using HA to follow up on the monitoring of expenditures on reproductive, neonatal, maternal, and child health (42). Linked initiatives, such as the Countdown to 2015: Tracking Progress in Maternal, Newborn \& Child Survival (now called Countdown to 2030), include financing and resource tracking data (43). This initiative and similar ones have underscored the importance of decisions that are supported by evidence-based interventions.

In a broader context, the path to universal health care requires essential financial information. Crucial is the extent of household financial protection. The level of out-of-pocket spending is recognized as a challenge to access to health care. Although not explicitly targeted by the Millennium Development Goals, household financial protection is a target of the Sustainable Development Goals. In the Americas, the level of outof-pocket expenditure has been challenged in the Strategy for Universal Access to Health and Universal Health coverage (4) as a barrier to access, and represents the most inefficient source of funding.

Essential information is provided by health accounts, using a homogeneous and internationally standardized system. HA provides comparable data over time and between countries, regardless of differences in health systems organization. The improvement of the measurement has become paramount. Increased quality of reporting, training, and control strategies (44) are part of the key actions to be implemented. It is expected that converging efforts related to the United Nations' Global Action Plan for Sustainable Development Data (45) will result in higher quality figures and improved registries, and thus, in better sources of information.

SHA 2011 encourages countries to develop standardized health expenditure monitoring, as a critical stewardship function of the national health authorities. In fact, the role of OECD and WHO, as well as the continued support of strategic partners, such as USAID, the World Bank, and IDB, are crucial to reach comparable statistics. To enhance the benefits of the available framework and guidelines, official translations in the main languages are desirable.

The use of HA data has not always been recognized through citations. However, HA offer a comprehensive overview of all financial flows of all actors. This is hardly done through other approaches, such as Public Expenditure Reviews, state, or Ministry of Health budgets and National Accounts. The potential of HA is still improving with experience. This is the case with OECD and WHO efforts to operationalize and standardize accounting for primary care.

The Region of the Americas faces problems also encountered in other areas, such as the scarce standardization of primary expenditure records, and when accounts have been produced, a lack of institutional memory to speed up continuity and permanence. The task of institutionalizing accounts (continuous production and strategic use of results) needs a national commitment, a skilled development effort, and a desire for transparency that goes beyond the public sphere to involve private actors. Good HA is the result of a country's commitment in all social and political spheres. LAC has the opportunity to enhance the complementary use of SNA satellite accounts and SHA in policymaking.

In general, the entities and individuals producing health accounts are not the policymakers and other users. HA are needed to facilitate better understanding and promote communication among these different actors. Fostering the use of accounts to support policies, by policymakers in each country, as well as by international agencies, is key to achieving institutionalization. In the Region of 
the Americas, $\mathrm{PAHO} / \mathrm{WHO}$ continues to have an important role to play in this area.

Acknowledgements. The authors wish to thank Jean-Pierre Poullier for prompting the production of this paper

1. Murray JLC, Evans DB, eds. Health systems performance assessment: debates, methods and empiricism. Geneva: WHO; 2003. Available from: www.who.int/ health_financing/documents/cov-hspa/ en/ Accessed 7 September 2017.

2. World Health Organization. Health systems financing: the path to universal coverage. World health report 2010. Geneva: WHO; 2010. Available from: www.who. int/whr/2010/en/ Accessed 7 September 2017.

3. World Health Organization. Sustainable health financing structures and universal coverage. Sixty-fourth World Health Assembly. Geneva: WHO; 2011. Available from: http://apps.who.int/medicinedocs/ documents / s21474en/s21474en.pdf Accessed 7 September 2017.

4. Pan American Health Organization. Strategy for Universal Access to Health and Universal Health Coverage. Proceedings of the $53^{\text {rd }}$ Directing Council. Washington DC: PAHO; 2014. Available from: www.paho. org/uhexchange/index.php/en/uhexchange-documents/technical-information / 26-strategy-for-universal-access-to-health-and-universal-health-coverage/file Accessed 10 October 2017

5. Bos F. The history of national accounting. The Hague: Statistics Netherlands; 1992. Available from: https://www.researchgate.net/publication/24114692_The History_of_National_Accounting Accessed 15 March 2018.

6. United Nations Statistics Division. Historic versions of the system of national accounts. New York: UNSD; 2010. Available from: http://unstats.un.org/unsd/nationalaccount/hsna.asp Accessed 7 September 2017.

7. European Commission. European System of Accounts, 2010. Luxembourg: EC; 2013. Available from: http://ec.europa.eu/ eurostat/documents/3859598/5925693/ KS-02-13-269-EN.PDF / 44cd 9 d 01 bc64-40e5-bd40-d17df0c69334 Accessed 7 September 2017. doi: 10.2785/16644.

8. United Nations, European Commission, International Monetary Fund, Organization for Economic Co-operation and Development, World Bank. System of National Accounts, 2008. New York: UN; 2009. Available from: https://unstats.un.org/unsd/nationalaccount/docs / SNA2008.pdf Accessed 7 September 2017.

9. Fetter B. Origins and elaboration of the National Health Accounts, 1926-2006. Health Care Financ Rev. 2006;28(1):53-67. Available from: https://www.ncbi.nlm. nih.gov/pmc/articles/PMC4194972/ Accessed 7 September 2017. and his role as one of the founding fathers of health accounting in OECD and WHO. We also wish to thank Leticia Avila and Daniel Aran for editorial comments and Laura Rivas for her contribution to the references and comments on a previous version.

\section{REFERENCES}

10. Waldo D. National Health Accounts: A framework for understanding health care financing. Health Aff. 2018;37(3):498-503. doi: $10.1377 /$ hlthaff.2017.1629

11. Centre de Recherches et de Documentation sur la Consommation. Dépenses de santé et revenu national. 1955;10(2):345-51. Available from: www.persee.fr/web/revues/home/prescript/article/pop_00324663_1955_num_10_2_4361 Accessed 7 September 2017

12. van Mosseveld CJPM. International comparison of health care expenditure: existing frameworks, innovations and data use. The Hague: Statistics Netherlands; 2003. Available from: https://www.narcis.nl/ publication/RecordID/oai\%3Arepub.eur. nl\%3A7909 Accessed 7 September 2017.

13. Statistischs Bundesamt. Facts \& Figures. Wiesbaden: DESTATIS; 2017. Available from: https://www.destatis.de/EN/Facts Figures/SocietyState/Health/Health.html Accessed 7 September 2017.

14. Abel-Smith B. Paying for health services a study of the costs and sources of finance in six countries. Public Health Papers. Geneva: WHO; 1963. Available from: http://apps. who.int/iris/bitstream/10665/39726/1/ WHO_PHP_17.pdf Accessed 7 September 2017.

15. Abel-Smith B. An international study of health expenditure and its relevance for health planning. Public Health Papers. Geneva: WHO; 1967. Available from: http://apps.who.int/iris/bitstream/ 10665/62927/1/WHO_PHP_32.pdf Accessed 7 September 2017.

16. Poullier JP. Public expenditure on health. Paris: Organization for Economic Cooperation and Development; 1977.

17. Gillion C, Schieber G, Poullier JP. Measuring health care, 1960-1983 expenditure costs and performance. Paris: Organization for Economic Cooperation and Development; 1985.

18. Berkley S, Bobadilla J-L, Hecht R, Hill K, Jamison DT, Murray CJL, et al. World Development Report 1993: investing in health. Washington, DC: World Bank; 1993. Available from: https://openknowledge. worldbank.org/handle/10986/5976 Accessed 7 September 2017.

19. Frenk J. Economía y salud: propuestas para el avance del sistema de salud en México. Mexico City: FUNSALUD; 1995. Available from: http://aleph.academica. $\mathrm{mx} /$ jspui/handle/56789/24113 Accessed 7 September 2017.

20. Portocarrero A. Las cuentas de salud y las políticas públicas en el Perú. Proceedings of the International Seminar on Health Accounts, 13 - 14 September 2017,
Conflicts of interest: None declared.

Disclaimer. Authors hold sole responsibility for the views expressed in the manuscript, which may not necessarily reflect the opinion or policy of the RPSP/PAJPH and/or PAHO.

Santiago, Chile. Santiago: $\mathrm{PAHO} / \mathrm{WHO}$; 2018. [Report forthcoming].

21. Berman P. National health accounts in developing countries: appropriate methods and recent applications. J Health Econ. 1997;6:11-30. Available from: https: / www. ncbi.nlm.nih.gov/pubmed/9142528 Accessed 7 September 2017.

22. van Mosseveld CJPM, van Son P. International comparison of health care data, methodology, development, and application. Voorburg/Heerlen: Kluwer Academic Publishers; 1999. doi: 10.1007/ 978-94-011-4675-3. Available from: https:/ / www.springer.com / g p / book / 9780792357155 Accessed 7 September 2017.

23. Organization for Economic Cooperation and Development. A system of health accounts. Paris: OECD; 2000. Available from: https:/ / www.oecd.org/els/health-systems/1841456.pdf Accessed 7 September 2017.

24. World Health Organization, World Bank, United States Agency for International Development. Guide to producing health accounts: with special applications to middle- and low- per capita income countries. Geneva: WHO; 2003. Available from: www.who.int/health-accounts/documentation/publication_nha_guide/en/ Accessed 7 September 2017.

25. World Health Organization. Health systems: improving performance. World health report 2000. Geneva: WHO; 2000. Available from: http:/ /www.who.int/whr/2000/en/ Accessed 7 September 2017.

26. Poullier JP, Hernandez P, Kawabata K, Savedoff W. Patterns of global health expenditures: results for 191 countries. In: Murray CJL, Evans DB, eds. Health Systems Performance Assessment: debates, methods, and empiricism. Geneva: WHO 2003. Available from: www.who.int/ pub/2003/hspa/en/ Accessed 7 September 2017.

27. Rannan-Eliya RP. Status of National Health Accounts in Asia Pacific Region: results of the APNHAN Survey 2001. Health Policy Programme. Colombo: Institute of Policy Studies; 2001. Available from: www.who. int/health-accounts/documentation/en/ Status_NHA_asia_pacific_region.pdf?ua=1 Accessed 7 September 2017.

28. Rathe M. Institutionalization of National Health Accounts: role of LAC Regional Network in supporting institutionalization activities. Report on the Action Plan to Promote Institutionalization, REDACS Annual Meeting. Santo Domingo: Fundación Plenitud; 2011. Available from: http: / / fundacionplenitud.org / files / REPORT\%20ON\%20THE\%20ACTION\% 
20PLAN\%20-\%20REDACS\%20MEETING. pdf Accessed 7 September 2017.

29. Pan American Health Organization. Manual on satellite health accounts. Washington: PAHO; 2005. Available from: http://www1.paho.org/spanish/ad/ge/ chile06-background15.pdf?ua=1 Accessed 7 September 2017.

30. Nakhimovsky S, Hernandez PP, van Mosseveld C, Palacios A. System of Health Accounts (2011) and Health Satellite Account (2005): comparison of approaches. Bethesda, MD: Abt Associates: 2014. Available from: https://www.hfgproject. org/wp-content/uploads/2014/08/SHA2011-and-Satellite-Accounts-FINAL.pdf Accessed 15 November 2017.

31. World Health Organization. The Abuja Declaration: ten years on. Geneva: WHO; 2011. Available from: www.who.int/healthsystems/publications/abuja_declaration/ en/ Accessed 15 November 2017.

32. Avila-Burgos L. Experiencia de México con las Cuentas en Salud: orígenes y aplicaciones para las políticas en salud. Proceedings of the International Seminar on Health Accounts, $13-14$ September 2017. Santiago: PAHO/WHO; 2018. [Report forthcoming].

33. Frenk J, Gómez-Dantés O, Langer A. A comprehensive approach to women's health: lessons from the Mexican health reform. 2012. BMC Womens Health. 2012:1242. Available from: https://www.ncbi.nlm. nih.gov / pmc/articles / PMC3543236/ Accessed 7 September 2017.

34. Izazola JA. Monitoring the declaration of commitment on HIV / AIDS \& UNGASS indicators. Geneva: UNAIDS; 2007. Available from: http://data.unaids.org/ pub/Presentation/2007/20080116_1_ monitoring_ungass_en.pdf Accessed $\overline{7}$ September 2017.

35. World Health Organization. Guide to producing malaria subaccounts within the national health accounts framework. Geneva: WHO; 2011. Available from: www.who.int/health-accounts/documentation/publication_HA_malaria/en/ Accessed 7 September 2017.

36. van Mosseveld C, Hernandez P, Morgan D. The pilot exercises of SHA 2011: lessons learned. Paris: Organization for Economic Cooperation and Development; 2014. Available from: https://www.oecd.org/ els / health-systems / Lessons $\% 20$ learned $\% 20-\% 20$ pilot $\% 20$ exercises $\% 20$ of $\% 20$ SHA $\% 202011$-version $\% 20$ feb 2014 . pdf Accessed 7 September 2017.

37. Maeda A, Harrit M, Mabuchi S, Siadat B, Nagpal S. Creating evidence for better health financing decisions: a strategic guide for the institutionalization of national health accounts. Washington DC: World Bank; 2012. Available from: https:/ / elibrary.worldbank.org / doi / abs / 10.1596/978-0-8213-9469-4 Accessed 7 September 2017.

38. European Union. Implementing Regulation No. 1338/2008 of the European Parliament and of the Council as regards statistics on healthcare expenditure and financing. Brussels: EU; 2015. Available from: http:// eur-lex.europa.eu/legal-content/en / A LL / ? uri=CELEX\%3A32015R0359. Accessed 7 September 2017.

39. Organization for Economic Cooperation and Development, EUROSTAT, World Health Organization. A System of Health Accounts 2011. Revised edition. Paris: OECD Publishing; 2017. http://dx.doi. org/10.1787/9789264270985-en. Available from: http://www.oecd.org/publications/a-system-of-health-accounts-20119789264270985-en.htm Accessed 7 September 2017.

40. World Health Organization. Global Health Expenditure Database Documentation Centre. (Internet). Geneva: WHO; 2017. http://apps.who.int/nha/database /
DocumentationCentre/Index/en Accessed 7 September 2017.

41. World Health Organization. Commission on Information and Accountability for Women's and Children's Health. Geneva: WHO; 2017. Available from: www. who.int/woman_child_accountability / about/coia/en/index5.html Accessed 7 September 2017.

42. Clinton H. Development in the 21st century. Washington, DC: Foreign Policy; 2010. Available from: www.foreignpolicy. com/articles/2010/01/06/hillary_clinton_on_development_in_the_21st_century Accessed 9 May 2018.

43. Countdown 2030. Countdown 2030: Maternal, Newborn \& Child Survival. Available from: http://countdown2030. org/ Accessed 9 May 2018.

44. van Mosseveld $C$, Hernández-Peña $P$, Arán D, Cherilova V, Mataria A. How to ensure quality of health accounts. Health Policy. 2016; 120(5):544-51. doi: 10.1016/j. healthpol.2016.03.009. Available from: www.healthpolicyjrnl.com / article / S0168-8510(16)30054-9/fulltext Accessed 7 September 2017.

45. World Data Forum. UN World Data Forum wraps up with launch of Cape Town Global Action Plan for Sustainable Development Data. Cape Town: UN; 2017. Available from: https://undataforum. org/WorldDataForum/wp-content/uploads/2017/01/ReleaseUNWDFclosing 18JanFinal.pdf Accessed 7 September 2017.

Manuscript received on 24 December 2017. Accepted for publication on 2 April 2018. 
RESUMEN Este informe sigue el rastro de la ampliación progresiva de las cuentas de salud para medir los gastos nacionales en salud, desde los primeros intentos de la Asociación Médica Estadounidense en 1926 hasta la actualidad. Se mencionan los hitos en la creación del Sistema de Cuentas de Salud (SCS), desde los antecedentes económicos y las acciones iniciales de unos cuanto países y organizaciones a la necesidad de un conjunto de normas de contabilidad para los sistemas de atención de salud y, por último, la consolidación con el Sistema de Cuentas de Salud del 2011. Varias organizaciones internacionales, como la Organización Mundial de la Salud, la Organización para la Cooperación y el Desarrollo Económicos, Eurostat, el Banco Mundial y la Agencia de los Estados Unidos para el Desarrollo Internacional, han sido fundamentales para ampliar los ejercicios nacionales de cuentas de salud y asegurar que estén normalizados, sean comparables y se institucionalicen.

Las acciones nacionales para realizar un seguimiento de los gastos en salud no solo han enriquecido los resultados colectivos, sino que se han convertido en un componente importante del liderazgo mundial, al fundamentar las políticas en todo el mundo. Más de 100 países han creado cuentas de salud de conformidad con la norma mundial, y han logrado una mejor comprensión del gasto en salud y de los flujos financieros. Estos resultados son clave para vigilar los avances relativos a las iniciativas nacionales y mundiales, como los Objetivos de Desarrollo Sostenible y la cobertura universal de salud. Todavía quedan retos por delante, como la institucionalización y la calidad de los resultados. También se necesita responsabilidad social para mejorar las fuentes de datos, y aumentar la generación y la facilidad de uso de las cuentas de salud.

Palabras clave Gastos en salud, normas; economía de la salud, historia; planificación en salud, economía; estrategias mundiales

RESUMO Este informe traça a progressiva expansão das contas da saúde para mensurar os gastos nacionais em saúde, das primeiras tentativas em 1926 pela Associação Americana de Medicina aos dias de hoje. Os marcos do desenvolvimento de um sistema de contas da saúde (SHA) são apresentados: dos antecedentes econômicos, esforços iniciais por parte de alguns países e organizações e necessidade de estabelecer um conjunto de normas contábeis para os sistemas de saúde à consolidação do sistema de contas da saúde (SHA) 2011. As organizações internacionais, como Organização Mundial da Saúde, Organização para a Cooperação e Desenvolvimento Econômico, Eurostat, Banco Mundial e Agência dos Estados Unidos para o Desenvolvimento Internacional, têm sido peças fundamentais para expandir os exercícios de contas nacionais da saúde e assegurar sua padronização, equivalência e institucionalização. Os esforços nacionais para monitorar os gastos em saúde não apenas melhoram os resultados coletivos, mas também são um importante componente de liderança global, servindo de base para políticas no mundo todo. Mais de 100 países criaram contas da saúde segundo o padrão global e têm agora um melhor entendimento do gasto em saúde e fluxos financeiros. Esses resultados são essenciais para monitorar o progresso rumo às iniciativas nacionais e globais, como os Objetivos de Desenvolvimento Sustentável e a cobertura universal de saúde. Existem ainda desafios a serem vencidos, como institucionalização e qualidade dos resultados. Também é preciso responsabilidade social para melhorar as fontes de dados e expandir a geração e a usabilidade das contas da saúde.

Palavras-chave Gastos em saúde, normas; economia da saúde, história; planejamento em saúde, economia; estratégias mundiais. 